\title{
Duration of ship-following by Kittiwakes Rissa tridactyla in the Barents Sea
}

\author{
KJELL EINAR ERIKSTAD, JAN OVE BUSTNES AND ODD JACOBSEN
}

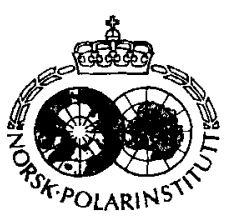

\begin{abstract}
Erikstad, K. E., Bustnes, J. O. \& Jacobsen, O. 1988: Duration of ship-following by Kittiwakes Rissa tridactyla in the Barents Sea. Polar Research 6, 191-194.

Ship-following Kittiwakes Rissa tridactyla were caught and dye-marked with picric acid on three occasions from a ship trawling in the Barents Sea in August 1986. The ship trawled regularly every 20-30 nautical miles and most of the trawl contents were fed to the birds accompanying the ship. Kittiwakes followed the ship for an average of 480-591 min. Between trawl-stations the birds rested on lifeboats and on the rail of the ship, and resting birds showed aggressive behaviour towards neighbours and intruders. The mean departure rate ranged from 4.2 to $5.1 \%$ per hour, and the turnover rate was 32 hours. It is obvious that the Kittiwakes behaved opportunistically and had adapted to exploit the waste from the commercial fisheries in the area.
\end{abstract}

Kjell Einar Erikstad, Jan Ove Bustnes and Odd Jacobsen, Marine Biology and Zoology Departments, Troms $\emptyset$ Museum, University of Troms $\phi$, N-9000 Troms $\emptyset$, Norway; March 1988 (revised September 1988).

Some seabirds, like the Kittiwake Rissa tridactyla, Northern Fulmar Fulmarus glacialis, skua (Stercorarius) species and different gull (Larus) species are attracted to fishing boats (Murphy 1914; Wahl \& Heinemann 1979; Watson 1981; Griffiths 1982; Abrams 1983; Tasker et al. 1984). These birds are pelagic feeders and waste from fisheries provides a ready supply of food, including items not naturally available to them.

Birds attracted by ships constitute a large part of the pelagic seabird community and some species have increased in number since 1900 , probably as a result of extra food supply from fisheries (Fisher 1952; Furness 1984). However, their behaviour towards ships complicates any attempt to estimate their distribution and density at sea. In some studies their number is overestimated because of the tendency for an observer to recount individuals, while in other studies they are omitted (see La Cock \& Schneider 1982).

The only study which has so far addressed this problem is that of La Cock \& Schneider (1982). They observed differently plumaged Wandering Albatrosses Diomedea exulans off the coast of South Africa and timed how long individuals followed the ship.

During an autumn cruise in the Barents Sea, we attempted to describe the extent of ship-following by marked Kittiwakes. As far as we know, the ship-following behaviour of marked birds has not been described before.

\section{Study area and methods}

Field work was carried out on board the research vessel G. O. Sars $(70 \mathrm{~m})$ between 24 and 30 August 1986 during a survey of 0-group (fry) fish between the coast of North Norway and Spitsbergen (Fig. 1).

The vessel trawled every 20-30 nautical miles and, after the trawl contents had been sorted, they were thrown overboard. The birds accompanying the ship fed on this fish.

We caught and dye-marked Kittiwakes on three different occasions (Fig. 1). I: 24 August, 22 birds were caught at $75^{\circ} 19^{\prime} \mathrm{N}, 29^{\circ} 33^{\prime} \mathrm{E}$, north-east of Bjørnøya while the ship was heading north towards Spitsbergen. II: 27 August, 11 birds were caught at $73^{\circ} 24^{\prime} \mathrm{N}, 25^{\circ} 38^{\prime} \mathrm{E}$, south-east of Bjørnøya on a course south towards Norway. III: 29 August, 21 birds were caught at $74^{\circ} 11^{\prime} \mathrm{N}, 23^{\circ} 38^{\prime} \mathrm{E}$, east of Bjørnøya on a course north towards Spitsbergen.

All marked birds were adults, but juvenile (both first and second year) plumaged birds were seen, both accompanying and resting on the boat.

Although we did not know for exactly how long the Kittiwakes had accompanied the ship before each experiment, the experiments were designed to minimize this problem. The distribution of Kittiwakes in the area was very patchy (unpublished data) and each experiment was started when large flocks of birds suddenly gathered around the ship. 


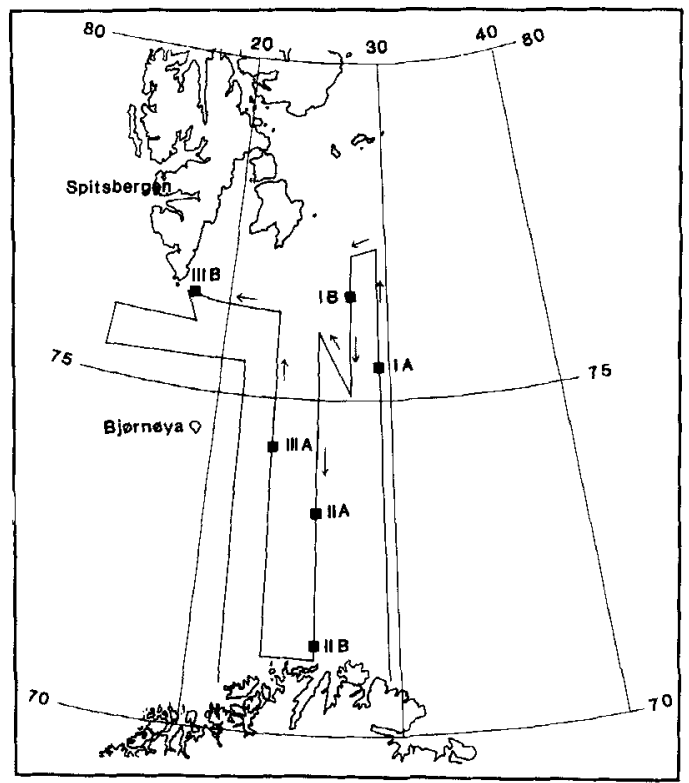

Fig. 1. Map of the Barents Sea showing the route of R.V. G.O. Sars and the position where Kittiwakes were caught, dyemarked and released (IA, IIA, IIIA) and when the last dyemarked bird was seen (IB, IIB, IIIB) in each experiment.

All birds were caught with a net while they were sitting on the rail of the ship. They were ringed and dye-marked on the head and chest with picric acid dissolved in alcohol, using different patterns in each experiment. Dyed birds were kept in large boxes to dry before they were all released simultaneously. Numbers of dye-marked birds seen from the top of the bridge were then noted every hour.

The average speed of the ship while trawling was 2-3 knots, and trawling lasted 30-45 minutes. The speed between trawl stations was 9-10 knots.

\section{Results}

The behaviour of ship-following Kittiwakes varied according to the activity on board the ship. When the trawl was shot, birds started circling and gathered in large flocks behind the ship. When hauling, birds followed closely, and when the net was lifted they fed on any fish discharged or thrown overboard.

Between trawl stations birds rested on the ship, either on the lifeboats or on the rail. At times several hundred Kittiwakes would follow the ship, and there appeared not to be enough room on board for them all. Resting birds were aggressive towards neighbours and intruders, using postures and signals similar to those used when defending the nesting area (e.g. Paludan 1955).

The behaviour of birds during the three experiments was very similar. For the first half hour after their release, all birds were seen either resting or circling the ship. Their number then gradually decreased (Fig. 2) and their departure rate could be described according to the decay function, $F_{t}=F_{0}^{e-k t}$ (see also La Cock \& Schneider 1982), where $F_{t}=$ the number of birds remaining at the time $t, F_{0}=$ the initial number of birds, $t=$ time, and $\mathrm{k}=$ constant.

$\mathrm{K}$ was estimated according to the straight line conversion $\ln F t=\ln F_{0}-k t$ and regressing $\ln F_{t}$ against $t, F_{0}$ being the $y$-intercept and $k$ the slope of the regression. This function gives a good description of the data in Fig. 2. The predicted variance was high in all three experiments $(0.94$ 0.98 , Table 1).

This function was then used to calculate the departure rate of the marked birds which ranged from 4.2 to $5.1 \% \mathrm{hr}^{-1}$. The overall turnover rate for all three experiments was 1919 minutes $(32 \mathrm{hrs}$, Table 1$)$. After 7 hours only half the Kittiwakes had departed, and even after 12 hours, $25 \%$ of the birds were still present.

One bird which remained on the ship for 78 hours, and was obviously in bad condition, was omitted from the calculations.

The mean duration of ship-following ranged from 480 to $591 \mathrm{~min}$. The standard deviation was

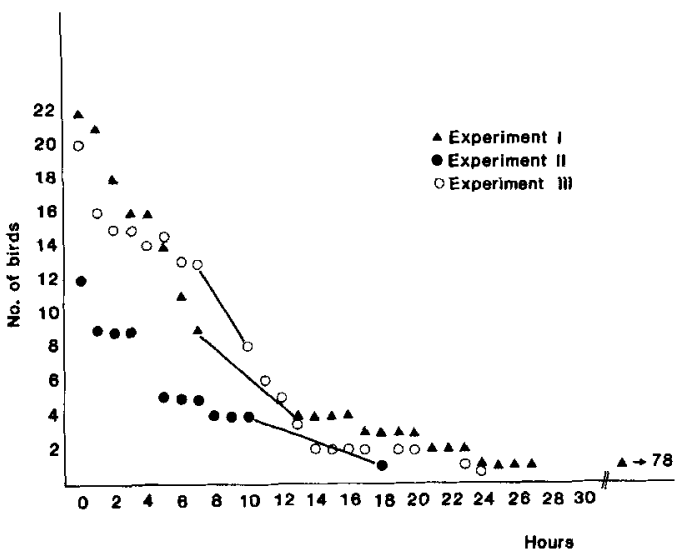

Fig. 2. Departure rate of dye-marked Kittiwakes in the three experiments. Solid lines indicate periods of darkness (2200 0300). 
Table 1. Decay function, predicted variance, estimated rate of loss per hour and other parameters for marked ship-following Kittiwakes in the Barents Sea, August 1986. $\mathrm{N}=$ sample size.

\begin{tabular}{|c|c|c|c|c|c|c|c|c|}
\hline & \multirow[b]{2}{*}{$\mathbf{N}$} & \multirow[b]{2}{*}{ Decay function } & \multirow{2}{*}{$\begin{array}{l}\text { Variance } \\
\left(\mathrm{r}^{2}\right)\end{array}$} & \multirow{2}{*}{$\begin{array}{l}\text { Estimated } \\
\text { rate of } \\
\text { loss }(\%) / h\end{array}$} & \multirow{2}{*}{$\begin{array}{l}\text { Estimated } \\
\text { turnover } \\
\text { time (min) }\end{array}$} & \multicolumn{2}{|c|}{$\begin{array}{l}\text { Duration of ship } \\
\text { following (min) }\end{array}$} & \multirow[b]{2}{*}{ Median } \\
\hline & & & & & & Mean & $\mathrm{SD}$ & \\
\hline Exp. I & 22 & $\mathrm{Ft}=22.42 \mathrm{e}^{-0.0018 t}$ & 0.98 & 4.9 & 1227 & 529.1 & 445.0 & 390.0 \\
\hline Exp. II & 11 & $\mathrm{Ft}=10.70 \mathrm{e}^{-0.0022 \mathrm{t}}$ & 0.97 & 5.1 & 1185 & 480.0 & 451.5 & 300.0 \\
\hline Exp. III & 21 & $F t=20.49 e^{-0.0021 t}$ & 0.94 & 4.2 & 1438 & 591.4 & 371.0 & 600.0 \\
\hline Total & 54 & $\mathrm{Ft}=56.26 \mathrm{e}^{-0.0021 \mathrm{t}}$ & 0.97 & 3.2 & 1919 & 545.6 & 433.3 & 470.0 \\
\hline
\end{tabular}

consistently large, and the median was considerably less than the mean in experiments 1 and 2 , suggesting that there was a tendency for some birds to follow the ship for longer periods than others (Table 1).

\section{Discussion}

There are no published quantitative descriptions of the ship-following behaviour of Kittiwakes and the mean time spent following the ship (545 min) is far longer than that described for other species in other areas.

The mean duration of ship-following for 8 species (albatrosses, petrels) in the Southern Ocean ranged from 4 to 80.5 min (Griffiths 1982). This was, however, a minimum estimate as no birds were marked. Attempts were made to keep an eye on the same bird, but after longer periods the identification of that bird became uncertain.

La Cock \& Schneider (1982) estimated the duration of ship-following by Wandering Albatrosses to be $57.2 \mathrm{~min}$, which was very similar to Griffiths' (1982) estimate of 80.5 min for the same species. Although La Cock \& Schneider (1982) observed birds of different plumages, their method had the same limitations as it is impossible to keep one's eye on the same bird for long periods.

According to Griffiths (1982), the mean duration of ship-following for three Antarctic Fulmars Fulmarus glacialoides was $11.3 \mathrm{~min}$. This agrees well with incidental data we collected in the Barents Sea. Seven Northern Fulmars were treated in the same way as the Kittiwakes, but none were seen for more than an hour after release. Although we stopped this experiment with Fulmars as they appeared to behave abnormally, there is little doubt that their turnover rate is much higher than that of the Kittiwakes. The Fulmars readily exploited any food thrown over- board, but seldom followed the ship to the next trawl station.

The need for good estimates of the density and distribution of seabirds at sea has increased recently. The offshore oil industry has developed rapidly, while marine ecologists have realized that seabirds are an important element in the marine ecosystem (e.g. Furness 1984). Counting birds at sea is no easy task and there have been considerable developments towards standardized methods. Tasker et al. (1984) conclude that shipfollowing birds should be omitted in the normal calculation of bird density and might be counted separately once an hour. This will give a measure of their number and distribution. Because more than $95 \%$ of the birds follow the ship for at least one hour (Table 1), Kittiwakes should probably be sampled at longer intervals. The complete turnover time was estimated to c. $32 \mathrm{hrs}$, and even by counting Kittiwakes every 8 hrs nearly $40 \%$ of the birds would have been counted twice. It is of course difficult to compare our results with those of other studies as the extent of ship-following may vary according to factors like the fishing activity of the vessel from which counts are made, the proximity of other actively fishing vessels, the time of year, etc. (Watson 1981).

The Barents Sea is heavily exploited by commercial fisheries (cod Gadus morhua, capelin Mallotus villosus and haddock Melanogrammus aeglefinus) for most of the year, and this study suggests that Kittiwakes behave opportunistically and have readily adapted to this extra food source. That they follow ships for much longer periods than albatrosses and petrels in the Southern Ocean may be a result of the Kittiwakes' ability to rest on the vessel between 'feeding stations'. The Glaucous Gull Laris hyperboreus and the Northern Fulmar, which also frequently follow ships in the Barents Sea, only occasionally (the Fulmar never) rested on the vessel. 
An important question is why birds should leave the ship having once found a steady food supply and a place to rest as suggested above. This experiment was carried out after the mormal breeding season which ends in late July in the Barents Sea area (Belopol'skii 1957), which means that there were no ties between the birds and their colonies. Although nothing is known about the quality of meals, the timing of meals was very similar during the whole cruise. One possibility is that Kittiwakes move about between the large number of fishing boats in this area, and that subordinate birds move more quickly than others if there is a chance of getting food at another ship.

The extensive ship-following by Kittiwakes as described in the present study is presumed to have a large influence on their distribution at sea. Recent studies by Abrams $(1983,1985)$ and Ryan \& Moloney (1988) from the southern Benguela region have shown that trawling activity not only influences the distribution of different species, but also the composition of the whole pelagic seabird community. Abrams (1985) also suggested that population sizes of species which feed at trawlers had increased in this area, although this was questioned by Ryan \& Moloney (1988).

In the Barents Sea area the breeding population of Kittiwakes, in some of the colonies, has more than doubled during the last 20 years (Barrett \& Vader 1984). It is possible that increased trawling activity and the large amount of waste from the fisheries may have partly contributed to this population increase.

Acknowledgements. - This study is part of a larger project (FOBO) in the Barents sea, studying the relationships between seabird distribution and oceanographical and marine biological parameters. We acknowledge Arvid Hylen at the Fisheries Research Institute in Bergen for giving us working facilities on board and the captain, crew and scientists on board R.V. G.O.Sars for hospitality and help. Rob Barrett, Mark Tasker,
Wim Vader and two referees made improvements to the article. Rob Barrett also corrected the English. The project is financed by the Norwegian Research Council for Science and the Humanities.

\section{References}

Abrams, R. W. 1983: Pelagic seabirds and trawl-fisheries in the southern Benguela current region. Mar. Ecol. Progr. Ser. 11, 151-156.

Abrams, R. W. 1985: Pelagic seabird community structure in the southern Benguela region: changes in response to man's activities? Biol. Conserv. 32, 33-49.

Barrett, R. T. \& Vader, W. 1984: The status and conservation of breeding seabirds in Norway. Pp. 323-333 in Croxall, J. P., Evans, P. G. H. \& Schreiber, R. W. (eds.): Status and Conservation of the world's seabirds. ICBP Technical Publication 2.

Belopol'skii, L. O. 1957: Ecology of sea colony birds of the Barents Sea (Engl. transl. 1961 IPST. Jerusalem).

Fisher, J. 1952: The Fulmar. Collins, London, $496 \mathrm{pp}$

Furness, R. 1984: Seabird-fisheries relationships in the northeast Atlantic and North Sea. Pp. 162-169 in Nettleship, D. N., Sanger, G. A. \& Springer, P. F. (eds.): Marine Birds: Their feeding ecology and commercial fisheries relationship. Proc. Pacific Seabird Group Symp. Seattle, Washington, 6-8 Jan. 1982.

Griffiths, A. M. 1982: Reactions of some seabirds to a ship in the southern Ocean. Ostrich 53, 228-235.

La Cock, G. \& Schneider, D. C. 1982: Duration of ship following by Wandering Albatrosses Diomedea exulans. Cormorant 10, 105-107.

Murphy, R. C. 1914: Observations on birds of the south Atlantic. $A u k$ 31, 439-457.

Paludan, K. 1955: Some behaviour patterns of Rissa tridactyla. Vidensk. Medd. Dansk naturh. Foren. 117, 1-21.

Ryan, P. G. \& Moloney, C. L. 1988: Effect of trawling on bird and seal distributions in the southern Benguela region. Mar. Ecol. Prog. Ser. 45, 1-11.

Tasker, M. L., Jones, P. H., Dixon, T. J. \& Blake, B. F. 1984: Counting seabirds at sea from ships: A review of methods employed and a suggestion for a standardized approach. $A u k$ $101,567-577$.

Wahl, T. R. \& Heinemann, D. 1979: Seabirds and fishing vessels: co-occurrence and attraction. Condor $81,390-396$.

Watson, P. S. 1981: Seabird observations from commercial trawlers in the Irish Sea. Brit. Birds 74, 82-90. 